\title{
Historein
}

Vol 14, No 1 (2014)

On the Edge of History and Philosophy

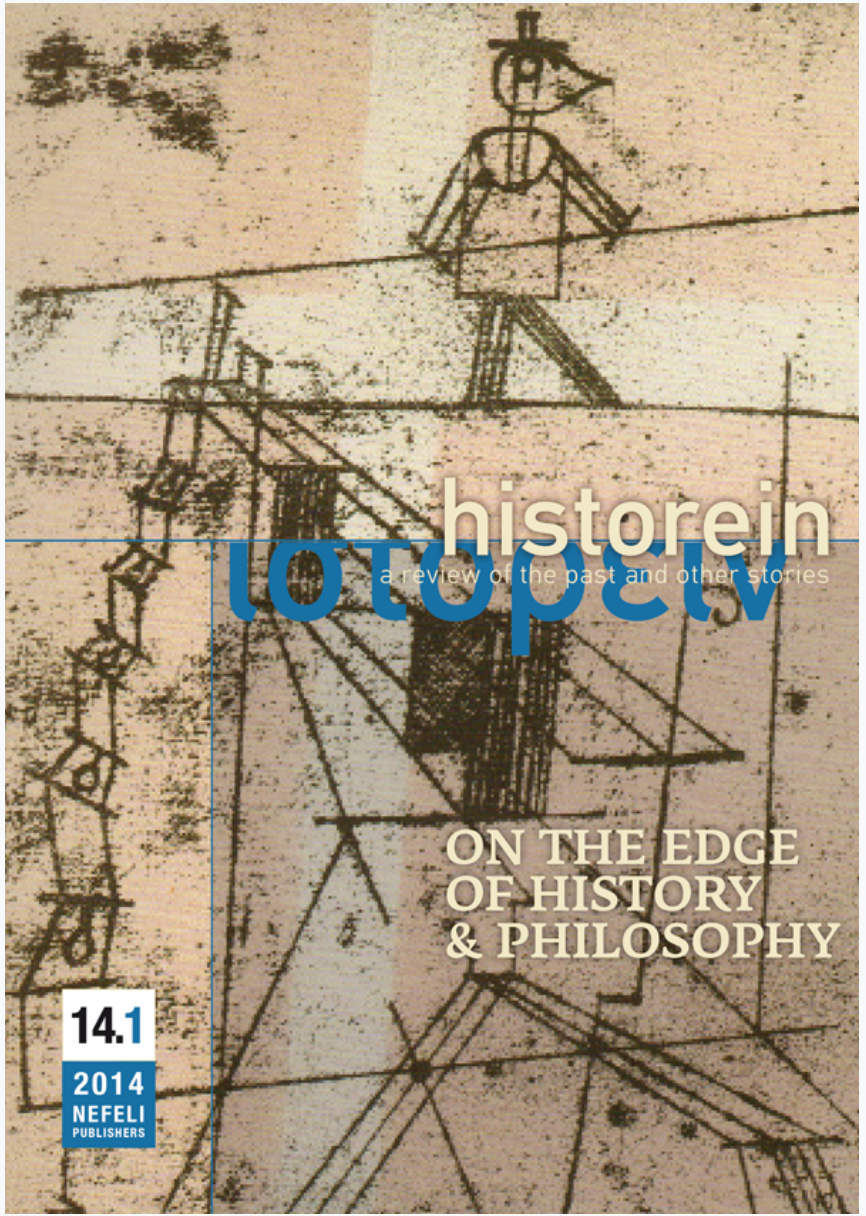

\section{Review of E. Robinson's History, Heritage and Tradition in Contemporary British Politics: Past Politics and Present Histories}

\author{
Emilia Salvanou
}

doi: $10.12681 /$ historein.252

Copyright @ 2014 , Emilia Salvanou

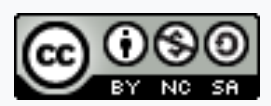

This work is licensed under a Creative Commons Attribution-NonCommercialShareAlike 4.0.

\section{To cite this article:}

Salvanou, E. (2013). Review of E. Robinson's History, Heritage and Tradition in Contemporary British Politics: Past Politics and Present Histories. Historein, 14(1), 142-146. https://doi.org/10.12681/historein.252 
they never penetrated male communities. This was the case, for instance, of the nurses who took care of Funder or of the female members of the master's family.

Papathanassiou's book is a substantial contribution to our understanding of essential features and complex interactions during the formative nineteenth century. Central European national identities in formation during the age of nationalism, labour consciousness in a rapidly changing work environment, religious attitudes in times of declining devotion, cultural practices as a means of social mobility, as well as gender representations in an age when the impact of the industrial revolution caused a sharp differentiation between gender roles, are eloquently discussed through the autobiographical records of these two Austrian artisans. The comparative approach of the two accounts within a 20 -year timeframe also offers a profitable chronological depth to her analysis. The study includes a comprehensive bibliography, a detailed map of the area covered by the two journeymen-confectioners and an English summary.

\section{Emily Robinson}

\section{History, Heritage and Tradition in Contemporary British Politics: Past Politics and Present Histories}

\author{
Manchester: Manchester University \\ Press, 2012. 208 pp
}

\section{Emilia Salvanou \\ University of Peloponnese}

How does history relate to politics? Does politics take into account the past when planning the future and in what way? In this book, Emily Robinson suggests that although the two are relevant, the way the past is incorporated in contemporary British politics has changed drastically since the 1980s. The past, according to Robinson, is no longer a political force. Being transformed into heritage, it is valued for its ability to be called on to provide an abstract continuity and to legitimise the present, without, at the same time, being "either a radical or a conservative force" (4). It has become a political commodity. Instead of serving as a starting point from which the present is challenged and progress is conceptualised, it largely serves to affirm the present - a condition that applies to all political parties, regardless their ideological orientation. The book's main argument is that, largely due to broader changes related to historical attitudes and the understanding of temporality, in contemporary British political parties the dominant attitude is presentism and history has been transformed into heritage. Politics, "rather than progress towards a promised future or historic destiny ... is based in an eternal, liminal present. It is always becoming history, becoming historic" (11).

The book is organised into an introduction and five chapters. The introduction sets the methodological and theoretical context of the essay, 
discussing the emergence of the "heritage industry" that followed the postwar memory boom and the way such overwhelming interest in the past has, at the same time, led to the historicisation of the present. In this context, Robinson continues, history was understood in emotional terms as heritage and thus a formative element of identity. Politics, on the other hand, was a preferential field for historical studies, leading to a close interrelation between political parties and professional-academic history, with political actors being interested in shaping the historical narrative of which they were part.

The first chapter, "Ideology and temporality", offers a thorough presentation of the way "conservatism" and "progressivism" gain their political power, not from the political programmes they are connected to, but from the assumption that they relate to a specific attitude towards historical movement: "Progressives" are assumed to "look forwards" and "conservatives" "backwards". By focusing on the way both conservatism and progressivism were expressed in bone and flesh within the British political parties (the Conservative, Liberal Democrat and Labour parties) at several points, the book convincingly shows that the use of such terms is highly ambiguous and definitely cannot be attributed exclusively to a single party. Rather, there are notions with temporal connotations, such as nostalgia, obligation to the past and political genealogies, progress, authenticity and modernity, to which all of the parties engage when dealing with the past and/or the future, while each of them elaborates on them in a different way. The common trends shared by the political parties, as far as shared temporal notions are concerned, can be understood, according to the chapter's main argument, only when contextualised within broader changes that have occurred mainly since the 1980s and which have changed the perception of what can be expected from the future. The establishment of neoliberalism and globalisation shaped a new postnational condition that is considered uncontroversial and sustainable. Perceiving the future not to be different from the present, in other words perceiving the present as permanent and unquestionable, deeply affected the way the political parties dealt with their past: it imposed a narrative of the past that silenced alterative voices on the future and worlds lost, and put itself in the service of the present, which was continuously historicised.

The second chapter, titled "Structures of memory: parties and their pasts", explores the way the relation to the past, discussed in the previous chapter, is materialised through historical practices. The chapter's main argument is that, despite differences in context and details, the similarities of the structures are striking, indicating a pattern in the function of such practices. Commencing from Pierre Nora's theory on historicised memory, Robinson explores the way the parties' structures of memory developed and changed gradually in the course of the twentieth century, to the point where they reached a level of convergence. Each party maintains an archive which is run by professional historians and academic researchers rather than party members, who, in turn are more interested in the political demands of the present. Their participation in cultivating the party's past consists mainly in the formation of volunteer history groups, which ensure the perpetuation of collecting archive records and marking new memory milestones. Thus, it seems that (mainly during the latter half of the twentieth century) that the task of constructing and diffusing collective memories in contemporary British political parties has been mostly entrusted to interested individuals, who, across the parties, seem to share homogeneous memory discourses. The key theme 
of memory practices in contemporary British parties seems to be an emphasis on the institutional past and the marking of everyday politics as history, underlining in this way their link to a presentist attitude towards time.

The next three chapters examine the use of the past across the parties at moments when political repositioning occurred. Chapter three, "Against the tide of history: conservatism in the 1980s and 1990s", revolves around two themes: Firstly, the Conservative party's adaptations after its electoral loss in 1997 in order to rationalise the defeat and put it in a historical frame, taking into account the legacy of Thatcher's leadership and her ambiguous relation with the past. According to Robinson, the defeat was devastating for the party, which in its attempt to deal with it undertook two major tasks: internal reorganisation, which led to a turn to the party's institutional past in the search for consolidation and inspiration, and a reflection on the party's ideological past, in order to seek consolidation, inspiration and reflection on the party's ideological past, to seek new, more convincing, ways to connect to the national past and, therefore, to broader strata of the electorate. Secondly, the chapter focuses on the debate over the national history curriculum, which brought to the fore the connections between history and national identity and generated intense interest not only among academic historians, educators and politicians, but the press and the public as well. During the 1980s, the Conservatives were alarmed because they feared they had no influence in historical education, which they perceived was dominated by the left and by themes that did not resonate with subjects of national significance. In that context, a debate over "what is the purpose of history teaching" emerged in which arguments revealing of the major attitudes towards the past were articulated. Historical knowledge and historical interpretation were the two keywords that disguised the Conservatives' fear that "national history - indeed national identity - would be lost in a sea of doubt and relativism". (108) Nevertheless, the divisions and disagreements that occurred cannot easily be attributed to rifts between the political parties; even though all the parties agreed on a number of points, they each had their own internal divisions as well. For example, even if postmodern historiography was related to the left, it holds equally true that the socialist historiography that sought to reveal the "actual" life of the marginalised groups of the past was, in many cases, uneasy with the deconstructionist approaches. Equally, it was not as if all Conservatives favoured grand narrative historiography, with the more intellectual part especially being sceptical about a coherent romanticised narrative of progress - a narrative that was much closer to Thacher's dehistoricised Victorian past. What seems, though, to be a point of consensus between parliamentarians is that history should be written backwards, from the present to the past, and contain a political narrative that presents a version of the institutional and parliamentary history of the parties, glorified in the contemporary power enjoyed by parliament.

Chapter four, "Negotiations with Labour's past: the SDP and New Labour", examines the way narratives of the past, and specifically Labour's, functioned both within the Social Democratic Party and New Labour. In both cases, the past held a central role in legitimising the identities and the genealogies of the political formations. In the case of the SDP, there was a constant attempt to maintain continuity with its Labour inheritance, especially because of its separation from the Labour party. The SDP sought legitimation in a part of Labour's past that it considered authentic (pre-1918) and criticised Labour for its subsequent choices. On the other hand, New Labour was in no need 
to prove continuity as extensively since there was no break with the party. On the contrary, in its rhetoric it underlined its "newness" and its "orientation towards the future". New Labour did not reject the party's past - it reformulated it so as to align it with the needs of the present. Through a thorough presentation of the discussions connected with the revision of Clause IV, Robinson provides an outline of the way Tony Blair incorporated and appropriated the entire revisionist history of the party into the content of his political narrative, while at the same time rhetorically proclaiming the modern and present-oriented character of New Labour's political programme.

Finally, the last chapter discusses the collapse of the Communist Party of Great Britain, especially after 1989 and the dissolution of the Eastern bloc. It focuses on the developments during the final four years of the party (1988-1991) and the way it renegotiated its attitude towards the past, after the departure of groups from it and the formation of the Communist Party of Britain. The chapter's basic point is that in the case of the CPGB, the negotiation of the past was more crucial compared to other political parties, because historical teleology is at the core of Marxism and because the communist identity had left a deeper mark on the personal life of its members compared to other political identities. The past was of such significance for the communist identity, so that when it was revised it "was not intended to justify future changes; changes were made necessary because of a new perspective of the past". By thoroughly presenting the developments through which the past was debated within the party's history groups and journals and the way disagreements over the interpretation of communist history led to separatist movements in the party, Robinson underlines the close interrelation of heritage and politics in the CPGB case. But it was not only the past that was being debated here. The collapse of communist regimes after 1989 made the future uncertain and called into question the Marxist conception of time. In their attempt to find a place in a drastically altered framework, CPBG members developed different strategies for taking responsibility of the past, updating their self-identification according to present notions and devising new narratives of communism to absorb the recent changes - in other words, by adopting a presentist approach to their past.

Robinson's essay is a thorough analysis both of the interrelation of politics and the past and the way the heritage industry has affected the historical consciousness of contemporary Britain. The past is presented as being of major importance to the formation and legitimation of politics, although it is not the historical past that is important, but "pastness" as a rhetorical device. It is the sense of "pastness", of continuity and heritage, that offers politics its legitimisation. In this way, the argument continues, the past is constructed in order to serve the needs of the present, which has hijacked two other temporal stages of significance. Such presentism can only be understood if contextualised within a broader cultural trend of heritage and nostalgia. On the other hand, though, it is exactly this nostalgic approach of the past as heritage that strips it of its transformative power to form future utopias, as it thoroughly washes out all dynamics and oppositional powers from it. Furthermore, the insistence on focusing on the present is seen as part of posthistorical and end-of-history discourses. Although it is debatable that humanity has reached the end of history, at least according to the Hegelian scheme of happiness, it seems like the establishment of the hegemony of neoliberalism in recent decades has temporarily led to a lack of vision for a differ- 
ent future, which would in turn give new dynamics to historical consciousness.

Being part of the scholarship on historical culture, memory studies and historical consciousness, Robinson's book, drawing on contemporary British history, sheds light on the way ideology and politics, past and future, historical consciousness and historical culture interrelate in complex and interdependent ways. It is due to its thorough theoretical base and the clarification offered by the cases analysed that the essay should attract a readership not only among historians and political scientists, but from all well-informed citizens.
Jack L. Davis and Natalia VogeikoffBrogan (eds)

\author{
Philhellenism, Philanthropy, or \\ Political Convenience? American \\ Archaeology in Greece
}

\section{Special issue of Hesperia 82/1 (2013). 227 pp.}

\section{Dimitris Plantzos \\ University of Athens}

The considerable number of foreign archaeological schools and institutes which have been operating in Greece since the mid-nineteenth century, only a decade or so after the country's independence, have helped construct, to the present day, an all-pervasive discourse on classical past and its uses. Though today mostly celebrated as "multidimensional research institutes and intermediaries between the Greek state and foreign scholars", whose "contribution is invaluable and unquestionable" as "they investigate, promote and preserve a large number of archaeological sites, constantly adding new elements to the huge mosaic of Greek history and Greek civilisation", foreign archaeological schools active in Greece were once treated pretty much as thinly disguised colonial outposts serving their own countries' cultural and political agendas and most of them were doing precisely that. ${ }^{2}$ Recent years, however, have seen a more nuanced approach to such matters, allowing for the multiplicity, contradictions and inevitable inconsistencies inherent in these projects. The volume under review, a collection of articles which "lays foundations for a revisionist history of the American School [of Classical Studies at Athens]", as its editors put it in their introduction (11), admirably transcends the colonialist vs the colonised divide and the blackand-white historical accounts that are bound 